\title{
ROLE OF GENE-XPERT IN DIAGNOSIS OF SMEAR NEGATIVE PULMONARY TUBERCULOSIS
}

\author{
Deependra Kumar Rai ${ }^{1}$,Somesh Thakur ${ }^{2}$, Abhishek Kumar ${ }^{3}$, Chinki Anupam ${ }^{4}$, Asish Kumar ${ }^{5}$, Shyama Kumari ${ }^{6}$ \\ ${ }^{1}$ Assistant Professor and HOD, Department of Pulmonary Medicine, All India Institute of Medical Sciences, Patna. \\ ${ }^{2}$ Assistant Professor, Department of Pulmonary Medicine, All India Institute of Medical Sciences, Patna. \\ ${ }^{3}$ Senior Resident, Department of Pulmonary Medicine, All India Institute of Medical Sciences, Patna. \\ 4Junior Resident, Department of Pulmonary Medicine, All India Institute of Medical Sciences, Patna. \\ 5Junior Resident, Department of Pulmonary Medicine, All India Institute of Medical Sciences, Patna. \\ ${ }^{6}$ Post Graduate Resident, Dayanand Ayurvedic College, Siwan.
}

ABSTRACT

\section{BACKGROUND}

Tuberculosis continues to be a major public health problem worldwide, with 8 million cases and 1.3 million deaths each year. Sputum smears with chest X-ray (CXR), where available are the tests routinely applied for TB diagnosis. Gene-xpert has very high sensitivity in diagnosis of smear negative pulmonary tuberculosis and it has more roles especially in low to middle income country. The aim of the study to measure the role of gene-xpert in diagnosis of sputum negative pulmonary tuberculosis.

\section{MATERIALS AND METHOD}

This was hospital based cross-sectional study conducted by department of pulmonary medicine, All India Institutes of Medical Sciences, Patna. All the pulmonary tuberculosis suspects' patients with 2 negative Ziehl-Neelsen (ZN) sputum smears were evaluated by Gene-xpert testing to diagnose pulmonary tuberculosis patients.

\section{RESULTS}

The total 106 sputum negative patients evaluated for gene-xpert. Gene-xpert was positive for Mtb in 37 (37/106, 34.9\%) patients. So 2.86 patients to be tested to detect one gene-xpert positive pulmonary tuberculosis case. The prevalence of MDR in our study patients was $13.20 \%$ and in gene-xpert positive patients was 37.83 percentage (14/37). Cough and Anorexia were more significantly associated with positive result in gen-xpert. Number needed to test was lowest (1.86) for combination of symptoms such as cough fever and anorexia.

\section{CONCLUSION}

Gene-xpert assay mainly indicated for early detection of MDR-TB, particularly when applied to high-risk groups in accordance with WHO recommendation. Our study shows that it is useful test to confirm tuberculosis even in smear negative pulmonary tuberculosis.

\section{KEYWORDS}

Pulmonary Tuberculosis, Smear Negative, Gene-Xpert, Multi Drug Resistance.

HOW TO CITE THIS ARTICLE: Rai DK, Thakur S, Kumar A, et al. "Role of gene-xpert in diagnosis of smear negative pulmonary tuberculosis." Journal of Evolution of Medical and Dental Sciences 2015; Vol. 4, Issue 105, December 31; Page: 17034-17037, DOI: $10.14260 /$ jemds/2015/2578

\section{INTRODUCTION}

Tuberculosis continues to be a major public health problem worldwide, with 8 million cases and 1.3 million deaths every year. ${ }^{1}$ The most widely used test for TB, sputum smear microscopy has a sensitivity of only $50 \%$ for active cases, which contributes to delayed diagnosis resulting in continued transmission. 2,3 Sputum smear with chest X-ray (CXR), where available, are the tests routinely ordered for TB diagnosis. It is crucial to implement improved diagnostics in endemic settings if we want to achieve the targets of case detection, reduction in mortality, and prevalence of the disease. 4,5 Gene-xpert has very high sensitivity in diagnosis of smear negative pulmonary tuberculosis and it has crucial roles especially in low to middle income countries.

Financial or Other, Competing Interest: None.

Submission 11-12-2015, Peer Review 12-12-2015,

Acceptance 26-12-2015, Published 31-12-2015.

Corresponding Author:

Dr. Deependra Kumar Rai,

Assistant Professor and HOD,

Department of Pulmonary Medicine,

All India Institute of Medical Sciences,

Phulwarisharif,

Patna-801505,

Bihar.

E-mail: deependra78@gmail.com

DOI:10.14260/jemds/2015/2578
Xpert is the only fully automated real-time DNA-based test which can detect both TB and rifampicin resistance. 6

\section{AIMS AND OBJECTIVE}

1. To measure the role of gene-xpert in diagnosis of sputum negative pulmonary tuberculosis.

2. To identify the relation between clinical symptoms and gene-xpert outcome.

\section{MATERIALS AND METHOD}

\section{Type of Study}

Cross-sectional hospital based study.

\section{METHOD}

The study was conducted by department of pulmonary medicine, All India Institutes of Medical Sciences, Patna. As Institute is new in phase of development, yet to have facilities for MTB culture, and diagnosis of pulmonary tuberculosis has been made with help of chest $\mathrm{x}$-ray and sputum microscopy methods mainly. All the pulmonary tuberculosis suspects with 2 negative Ziehl-Neelsen (ZN) sputum smears were referred for testing at Gene-xpert Lab established by World health partner outside of institute. Patients were informed about the test and written informed consent sought to collect baseline data on demographics and symptoms at presentation.

This study was approved by the Institutional Ethical Committee, AIIMS Patna. 
All the baseline data including demography, history of Anti-tubercular treatment in past, clinical symptoms such as total duration of illness, cough more than 2 weeks, fever for more than two weeks, loss of appetite, hemoptysis in last 3 month and shortness of breath were entered.

Categorical variables were compared between patient groups testing positive and negative by Xpert using Fisher's exact test with a $P$ value of $\leq 0.05$ considered as significant.

\section{RESULTS}

The study was conducted between $13^{\text {th }}$ May 2015 to $31^{\text {st }}$ Aug 2015. The total 132 pulmonary suspects had negative smear for AFB by ZN staining. There were 20 patients who undergo only one sputum test and therefore excluded from the study. The total 112 patients who had two sputum sample negative for Acid fast bacilli referred for gene-xpert testing, but only 106 turn-up with gene-xpert report. MTB was detected in 37 $(37 / 106,34.9 \%)$ patients. So 2.86 patient has to be tested to detect one gene-xpert positive pulmonary tuberculosis case. All positive patients were started with daily anti-tubercular treatment.
Table 1 shows baseline characteristics of study patients and most of the patients were between age 15-30 years (53/106, 50\%). Female percentage was 34.9 (37/106). Gene xpert positivity rate was highest in age group of 15-30 years $(22 / 53,41.50 \%)$. There were not much differences in positivity rate between male \& female $(34.78 \%$ vs $35.13 \%)$. Patients who received ant-tubercular treatment in past had less gene xpert positivity rate in comparison to pulmonary tuberculosis suspects who never received ATT in past $32.75 \%$ vs $37.50 \%)$.

The majority of patients had high burden of MTB in genexpert testing (19/37, 51.35\%). The prevalence of MDR in genexpert positive patients was $37.83 \%(14 / 37)$ and if we compare to total study (Sputum negative), patient positivity was 13.20\% (14/106) (Table 2).

If we compare clinical symptoms, cough and Anorexia were more significantly associated with positive result in genxpert (Table 3). Number needed to test was lowest (1.86) for combination of symptoms such as cough fever and anorexia (Table 4).

\begin{tabular}{|l|c|c|c|c|c|}
\hline & & $\begin{array}{c}\text { Total Study } \\
\text { Patients } \\
\mathbf{( 1 0 6 )}\end{array}$ & $\begin{array}{c}\text { Gene Xpert } \\
\text { Positive } \\
\mathbf{( 3 7 ) ( 3 4 . 9 0} \\
\mathbf{\%}\end{array}$ & $\begin{array}{c}\text { Gene Xpert } \\
\text { Negative (69) } \\
\mathbf{( 6 5 . 0 9 \% )}\end{array}$ & $\begin{array}{c}\text { MDR } \\
\mathbf{1 4}(\mathbf{1 3 . 2 0} \%)\end{array}$ \\
\hline 1. Age (Yrs.) & $15-30$ & 53 & $22(41.50)$ & $31(58.49)$ & $10(71.42)$ \\
\hline & $31-45$ & 27 & $09(33.33)$ & $18(66.66)$ & $03(21.42)$ \\
\hline & $46-60$ & 19 & $04(21.05)$ & $15(78.94)$ & $01(0.07)$ \\
\hline & $>60$ & 07 & $02(28.57)$ & $05(71.52)$ & $00(0)$ \\
\hline 2. Gender & Male & 69 & $24(34.78)$ & $45(65.21)$ & $10(71.42)$ \\
\hline & Female & 37 & $13(35.13)$ & $24(64.86)$ & $04(28.57))$ \\
\hline \multirow{2}{*}{3. H/O ATT } & Yes & 58 & $19(32.75)$ & $39(67.24$ & $11 / 58(18.96)$ \\
\cline { 2 - 6 } & NO & 48 & $18(37.50)$ & $30(62.50)$ & $03 / 48(0.06 \%$ \\
\hline \multicolumn{7}{|c|}{ Table 1: Baseline characteristics of study patients } \\
\hline
\end{tabular}

\begin{tabular}{|c|c|c|c|c|}
\hline & & Total Patients & $\begin{array}{c}\text { Rifampicin Resistance } \\
\text { Detected ( MDR) }\end{array}$ & Percentage \\
\hline 2. & Gene Xpert & 106 & 14 & 13.20 \\
\hline & a. Positive & $37(34.90 \%)$ & 14 & 37.83 \\
\hline & High & $19(51.35 \%)$ & 10 & 52.63 \\
\hline & Intermediate & $11(29.72 \%)$ & 04 & 36.36 \\
\hline & Low & $06(16.21 \%)$ & 00 & 0 \\
\hline \multicolumn{2}{|c|}{ Very low } & $01(2.70 \%)$ & 00 & 0 \\
\hline & b. Negative & $69(65.05 \%)$ & 00 & 0 \\
\hline \multicolumn{6}{|c|}{ Table 2: Prevalence of MDR Pulmonary Tuberculosis in Gene-Xpert positive Patients } \\
\hline
\end{tabular}

\begin{tabular}{|c|c|c|c|}
\hline & $\begin{array}{c}\text { Gene-Xpert } \\
\text { Positive n (\%) }\end{array}$ & $\begin{array}{c}\text { Gene-Xpert } \\
\text { Negative n (\%) }\end{array}$ & $P$ value \\
\hline \multicolumn{4}{|l|}{ 1. One symptom } \\
\hline Cough & $33(89.18)$ & $62(89.85)$ & 0.9147 \\
\hline Fever & $21(56.75)$ & $25(36.23)$ & 0.0421 ( significant) \\
\hline Anorexia & $28(75.67)$ & $25(36.23)$ & 0.001 (significant) \\
\hline Hemoptysis & $09(24.32)$ & $29(42.02)$ & 0.07 \\
\hline SOB & $14(37.83)$ & 27 (39.13) & 0.89 \\
\hline \multicolumn{4}{|l|}{ 2. More than one symptoms } \\
\hline Cough + Fever & $19(51.35)$ & $23(33.33)$ & 0.0706 \\
\hline Cough+ Fever+ Anorexia & $16(43.24)$ & $11(15.94)$ & 0.0021 ( significant) \\
\hline Cough + Fever+ hemoptysis & $06(16.21)$ & $15(21.73)$ & 0.49 \\
\hline Total & $37(100)$ & $69(100)$ & \\
\hline $\begin{array}{r}\text { Table 3: Com } \\
\text { Smear }\end{array}$ & ive, Xpert po & $\begin{array}{l}\text { symptoms a } \\
\text { nd negative }\end{array}$ & $\begin{array}{l}\text { spected } \\
\text { ts }\end{array}$ \\
\hline
\end{tabular}




\begin{tabular}{|c|c|c|c|}
\hline Inclusion Criteria & Total & $\begin{array}{c}\text { Gene-Xpert } \\
\text { Positivity }\end{array}$ & Number Needed to Test \\
\hline Cough+ Fever & 42 & 19 & 2.21 \\
\hline Cough+ Fever+ Anorexia & 27 & 16 & 1.68 \\
\hline Cough+ Fever+ hemoptysis & 12 & 06 & 2 \\
\hline \multicolumn{2}{|r|}{ Table 4: Number of patients detected as positive by } \\
Gene Xpert using different symptoms criteria for testing \\
\hline
\end{tabular}

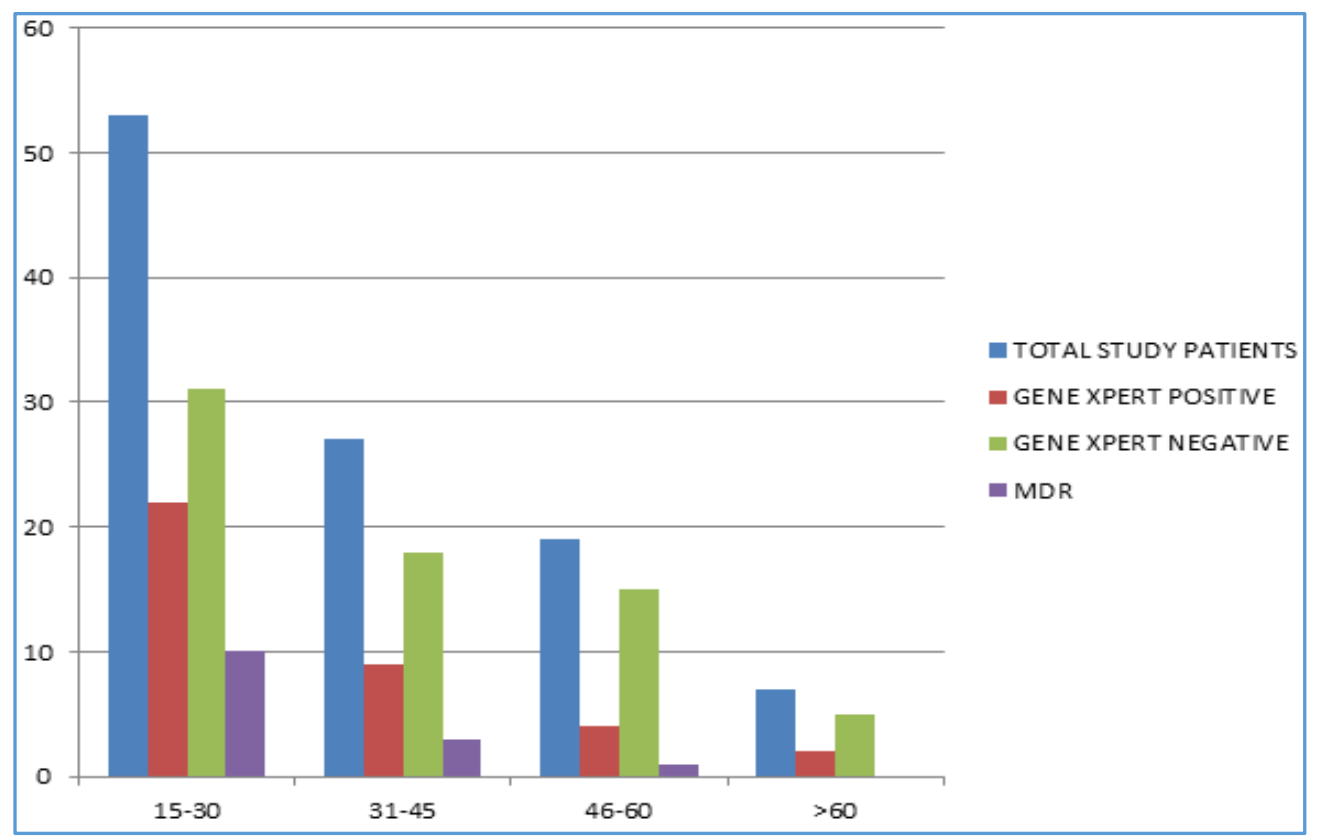

Fig. 1: Age wise Gene-Xpert result in smear negative patients

Number on Y axis represent percentage of total study patients

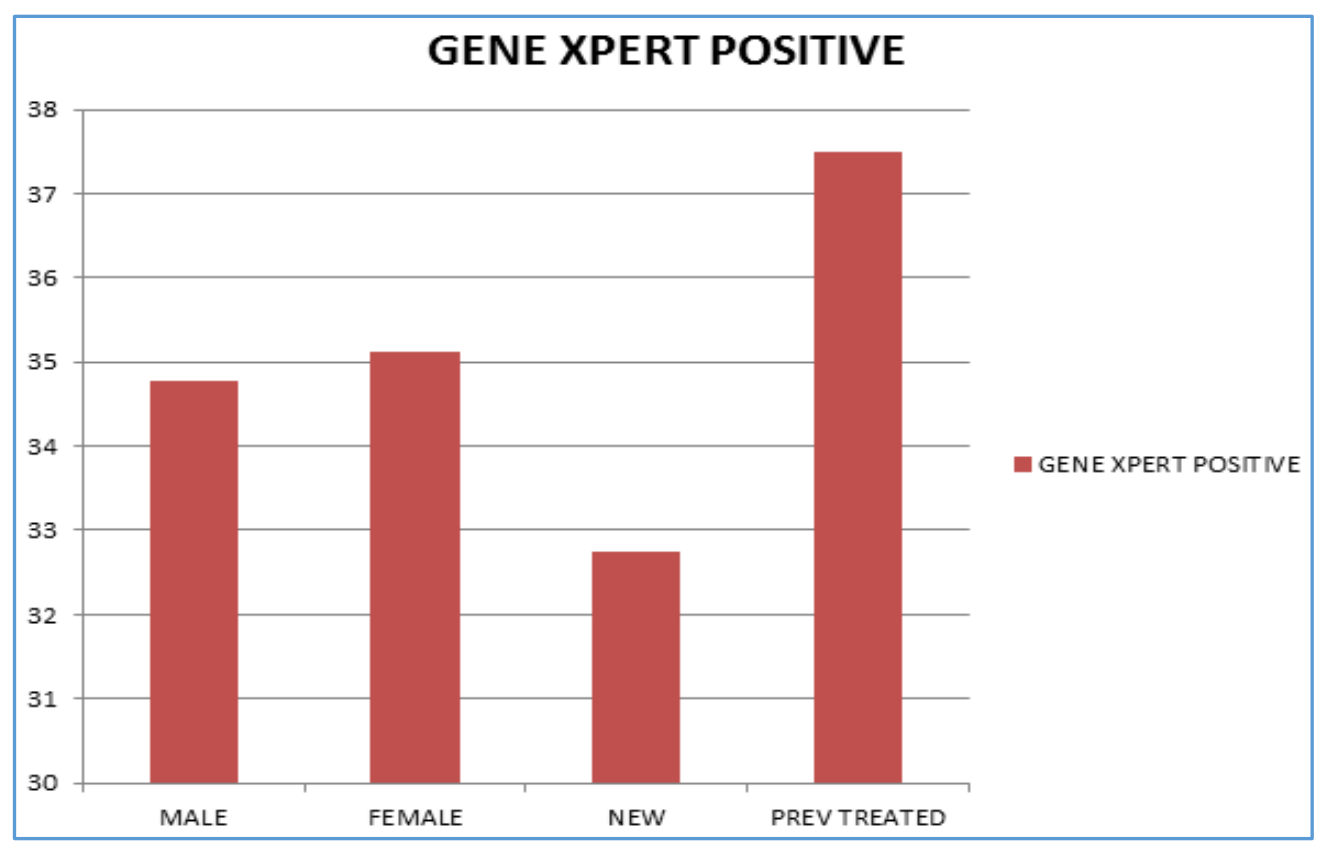

Fig. 2: Gender wise and history of Anti-tubercular treatment and Gene-Xpert positivity

Number on Y-axis represent percentage of Gene-Xpert positivity. 


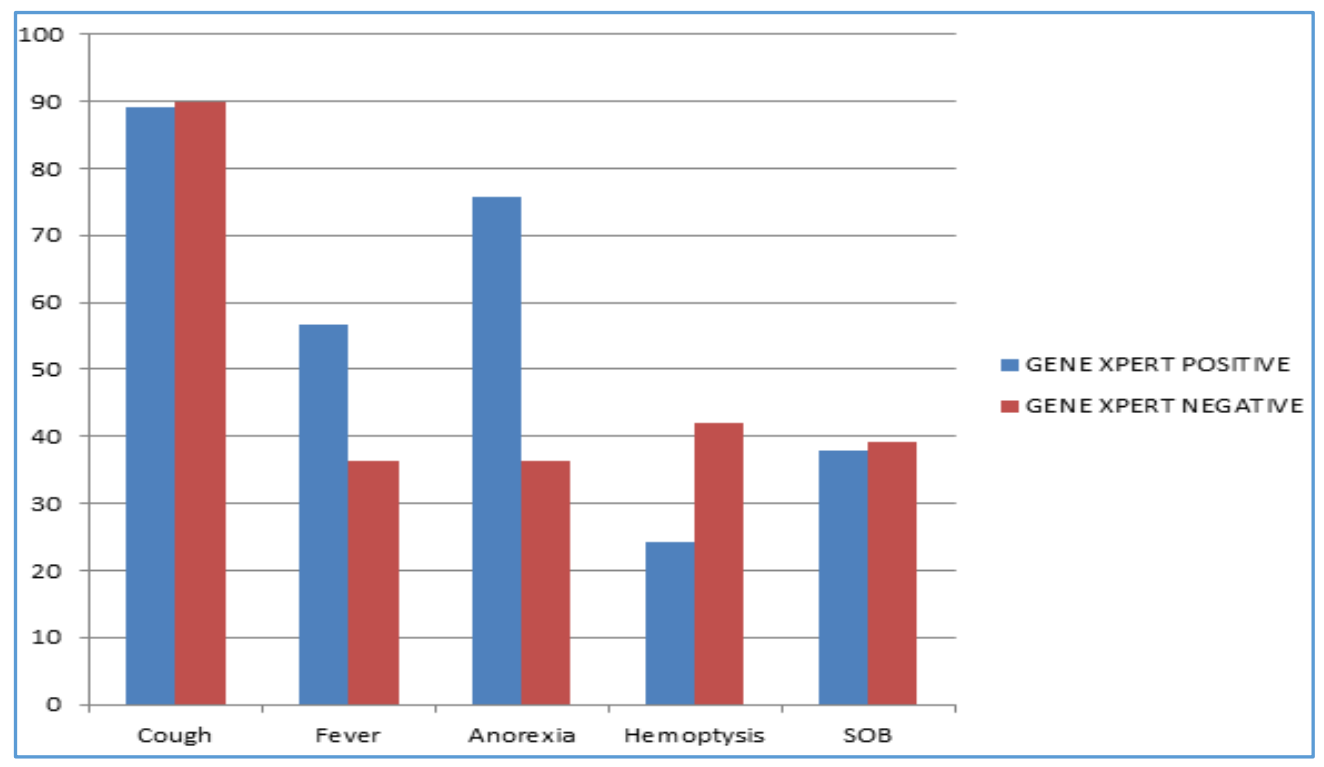

Fig. 3: Clinical symptoms predictor for Gene-Xpert positivity

Number on $\mathrm{Y}$ axis represent percentage of total patients with symptoms.

\section{DISCUSSION}

This study shows that Gene-xpert testing increases the detection of pulmonary tuberculosis cases and it also shows that at least 3.4 patients need to be tested to detect one genexpert positive pulmonary tuberculosis case. There are many studies. 7,8 which shows that specificity of test is very high which can be used as gold standard in place where culture facilities is not available. In India or other country where tuberculosis is endemic, diagnosis of tuberculosis depends mainly upon sputum AFB microscopy and chest X-ray. GeneXpert helps in confirming the diagnosis of sputum negative pulmonary tuberculosis cases. This test may not increase overall sputum negative cases initiated on treatment because treatment doesn't started due to AFB negativity. This studies shows that more than thirty percent of smear negative patients were diagnosed positive by this method. ${ }^{9}$ It is costly affair to subject all smear negative patients in our country. ${ }^{10}$ Our study shows that high intensity of infection present in more than half of gene-xpert positive patients.

Prevalence of Rifampicin resistance was found in more than ten percent of smear negative patients which is significantly high. There are no study to compare prevalence of multi drug resistance in sputum negative pulmonary suspect patients. Most of the rifampicin resistance was found in patient with high intensity of infection in gene-xpert and patients who received Ant-tubercular treatment in past. We measure the clinical features of groups testing positive and negative by Xpert to determine new testing criteria which could guide the application of Xpert and reduce unnecessary testing and thereby costs to the patient. The number needed to test was lowest (1.86) if we used combination of symptoms such as cough, fever and anorexia.

\section{CONCLUSION}

Gene-Xpert assay is mainly indicated for early detection of MDR-TB, particularly when applied to high-risk groups in accordance with WHO recommendation. Our study shows that it is useful test to confirm tuberculosis even in smear negative pulmonary tuberculosis.

\section{LIMITATION OF STUDY}

This study did not compare with gold standard sputum culture and so sensitivity and specificity cannot be calculated.
We did not assess HIV status, which is required to assess such high prevalence of MDR tuberculosis in our studies.

\section{REFERENCES}

1. World Health Organization, Global Tuberculosis Report, WHO/HTM/TB/2013.11, World Health Organization, Geneva, Switzerland, 2013.

2. Young DB, Perkins MD, Duncan K, et al. "Confronting the scientific obstacles to global control of tuberculosis." The Journal of Clinical Investigation, vol. 118, no.4, pp. 12551265, 2008.

3. Perkins MD and Cunningham J. "Facing the crisis: improving the diagnosis of tuberculosis in the HIV era." Journal of Infectious Diseases, vol. 196, supplement 1, pp. S15-S27, 2007.

4. Parsons' LM, Somosk"ovi A, Gutierrez C, et al. "Laboratory diagnosis of tuberculosis in resource-poor countries: challenges and opportunities." Clinical Microbiology Reviews, vol. 24, no. 2, pp. 314-350, 2011.

5. Urdea M, Penny LA, Olmsted SS, et al. "Requirements for high impact diagnostics in the developing world." Nature, vol. 444, supplement 1, pp. 73-79, 2006.

6. Helb D, Jones M, Story E, et al. "Rapid detection of mycobacterium tuberculosis and rifampin resistance by use of on demand, near-patient technology." Journal of Clinical Microbiology, vol. 48, no. 1, pp. 229-237, 2010.

7. Lawn SD and Nicol MP. "Xpert MTB/RIF assay: development, evaluation and implementation of a new rapid molecular diagnostic for tuberculosis and rifampicin resistance." Future Microbiology, vol. 6, no. 9, pp. 1067-1082, 2011.

8. Steingart KR, Sohn H, Schiller I, et al. "Xpert MTB/RIF assay for pulmonary tuberculosis and rifampicin resistance in adults." The Cochrane Database of Systematic Reviews, vol. 1, Article ID CD009593, 2014.

9. Vassall A, van Kampen S, Sohn H, et al. "Rapid diagnosis of tuberculosis with the Xpert MTB/RIF assay in high burden countries: a cost-effectiveness analysis." PLoS Medicine, vol. 8, no. 11, Article ID e1001120, 2011.

10. Dowdy DW, Cattamanchi A, Steingart KR, et al. "Is scaleup worth it? Challenges in economic analysis of diagnostic tests for tuberculosis." PLoS Medicine, vol. 8, no. 7, Article ID e1001063, 2011. 